Motshegwe, M.M. \& Batane, T. (2015). Factors Influencing Instructors' Attitudes toward Technology Integration. Journal of Educational Technology Development and Exchange, 8(1), 1-15.

\title{
Factors Influencing Instructors' Attitudes toward Technology Integration
}

\author{
Molefe Mookana Motshegwe \\ University of Botswana \\ Tshepo Batane \\ University of Botswana
}

\begin{abstract}
This study investigated factors that influence instructors'attitudes toward technology integration.The study was situated within the Technology Acceptance Model and conducted among university instructors $(N=63)$. A questionnaire was used to collect data from the participants. The results indicated that perceived usefulness and perceived ease of use positively influenced instructors' attitude s toward technology adoption. Self-efficacy was considered an external variable to evaluate its influenceon perceived usefulness, perceived ease, and attitudes. The findings showed that contrary to what similar empirical studies reported, in this study, self-efficacy had no influence on the aforementioned variables. The study attributes this lack of influence to the legitimacy of self-belief reports in providing credible information that can assist in determining people's actual experience with technology. The study concludes that self-efficacy cannot be used as a reliable tool predicting people's attitudes toward technology integration. Further, the study suggests that context in which self-efficacy is being measured may have an influence on what people believe is expected from them, as opposed to their actual experiences. A recommendationfor further investigation into other factors that may influence people's attitude such as cultural background and teaching philosophy is offered.
\end{abstract}

Keywords: Technology adoption, attitudes, self-efficacy, technology acceptance model, perceived usefulness

\section{Introduction}

The decision by instructors to reject or adopt technology in their teaching is a complex issue that remains a challenge for many institutions of higher learning. Studies reveal that despite a high infiltration of various technologies in educational settings, effective utilization of these resources in learning is still an uphill battle for many universities and colleges around the world (Ertmerr\&Ottenbreit-Leftwich, 2010; Kotrlik\&Redmann, 2009; Moser, 2007; Oye, Salleh, \&Iahad, 2011).At the University of Botswana (UB), integrationof technology in teaching is a problem that continues to trouble the university management. In 2001, the institution made a decision to make 
technology part of its teaching and learning processes.Over the years, several studies have been conductedto investigate technology usage and identify issues that affect integrationof technology use at the institution (Masalela, 2009; Molelu\& Thomas, 2008; Mutula, 2004; Thurab-Nkhosi, Lee,\&Gachago, 2005). These studies identified issues such as inadequate resources, large classes, technophobia, workloads, lack of time, lack of training, and lack of policy on eLearningas the main stumbling blocks to technology integration. The university has made efforts to address these issues, most significantly through intensifying technology training and support and increasing the availability of technology resources for both students and instructors. However, despite these efforts, reports continue to reveal unsatisfactory usage of technology by instructors in the delivery of their courses (Mafote\&Oluka, 2012). Mafote and Oluka(2012) reported that only $38 \%$ of instructors at UB have adopted technology and use it in their teaching. This has prompted the need to investigate this issue deeper and look beyond physical factorsto identify other aspects that may be affecting technology adoptionat the institution. Therefore, this study decided to look at the affective ramifications of technology integration, specifically attitudes.

Ajzen (1988) defines attitude as a complex conundrum of feelings, desires, and fears that create a state of readiness to act within a person. This study contends thatthe decision to use technology is not only determined by the availability of resources and training, but also influenced by an individual's philosophical and inner feelings about such a phenomenon. Therefore, attitudes play a significant role in this process. Staub (2009) says "technology adoption is a complex, inherently social, developmental process; individuals construct unique yet malleable perceptions of technology that influence their adoption decisions. Thus, successfully facilitating technology adoption must address cognitive, emotional, and contextual concerns" (p. 625). This study intends to provide some empirical data on the effects of some factors that influence one's attitude towards technology. Oigara and Wallace (2012), Hardin (2006), and Tabata and Johnsrud (2008)contend that the ability to use technology in teaching starts with instructors' attitudes toward technology. Thus, the goals of this study are (1) to investigate factors that influence instructors' attitudes toward technology, and (2) establish how these factors can be influenced to promote positive attitudes towards technology. The study is situated within the Technology Acceptance Model.

\subsection{Technology Integration}

Technology integration in this context refers to the use of technology resources such as computers, data projectors, video conferencing, VCRs and television sets, the Internet, Learning Management Systems, PowerPoint, Social Media, etc. in instructional activities, and in the management of a course as a whole.According to Staub (2009), adoption is not only the choice to accept an innovation, but also the extent to which that innovation is appropriately integrated within a specific environment. Instructors have to develop a culture that embraces technology and regard it as part of their business everyday work. Edutopia Staff (2012) also adds that technology adoption is achieved when the use of technology is a daily occurrence; instructors do not stop to think that they are using technology tools.

\subsection{Theoretical Framework of the study}

This study is situated within the Technology Acceptance Model (TAM). TAM has become a robust and powerful model for 
predicting user acceptance and also a key factor in helping to explain and predict user behavior of technology systems (Hsia \& Tseng, 2008; Jong \&Wang, 2009; Teo, Luan, $\&$ Sing, 2008). According to Park(2009), one's actual use of a technology system is influenced directly or indirectly by the user's behavioral intentions, attitudes, perceived usefulness of the system, and perceived ease of the system. Attitudes usually show themselves through one's behavior and can influence an individual's choice of action and responses to challenges (Sam, Othman, \&Nordin, 2005). According to this model, attitude is a critical driver of technology adoption. In addition, external variables affect intention and actual use through mediated effects on perceived usefulness and perceived ease of use (Park, 2009). The model is illustrated diagrammatically in Figure 1 below. might influence adoption depending on the research context. As Park, Lee, and Cheong (2007)say isnecessary to explore other constructs that would enrich the explanation of users' acceptance of technology systems. This study employed another variable that was believed to play an important role in instructors' decision to adopt technology beyond what the TAM suggests, this being self-efficacy.

\subsection{Self-efficacy}

Self-efficacy is the measure of one's own ability to complete tasks and reach goals(Ormrod, 2006). According to this concept, when people believe that they have the capability to successfully implement the behavioural action, they are more likely to engage in the behaviour;meaning that

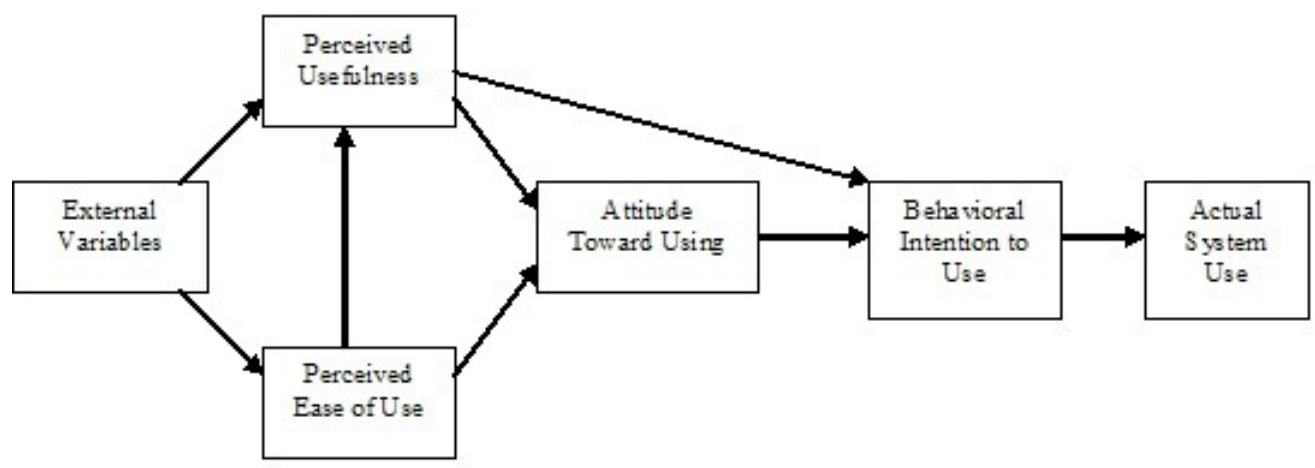

Figure 1. Technology Acceptance Model (Davis, 1989).

TAM provides guidance on how to influence usage through design and implementation (Venkatesh, Morris, Davis,\& Davis, 2003; Wixom \& Todd, 2005). For instance, the model provides feedback on usefulness and ease of use, but leaves room for researchers to explore other variables that they have high self-efficacy.In terms of technology integration, self-efficacy plays a crucial role in professionally guided and self-guided behavioral change strategies. Jaradat and Faqih (2014) say that selfefficacy is an important factor to consider when determining whether people will adopt 
new technologies. According to them, even if people are convinced about the benefits that a new technology may offer, if they are not confident in their own ability to use them they may not use technology. Self-efficacy is regarded as an important precursor to people' attitudes. A study by Bates and Khasawneh (2007) indicated that when students have successful and positive experiences with similar technologies, their self-efficacy for using those types of technologies increases. Several research studies have been conducted specifically on technology self-efficacy (Anderson, Groulx, \& Maninger, 2011; Decker, n.d; Khasawneh, 2007; Othman, \&Nordin, 2005;Seferoğlu, 2007; Teo, 2009). According to Seferoğlu (2007), technology self-efficacy of academic staff has an influence on the learning experiences created for learners and on the learners' perceptions of their own technology self-efficacy. That is, lack of confidence by instructors to use technology in their instructional activities can contribute to the learners' inabilities to use technology. He argues that because the academic staff role is to guide learners, they should feel secure in themselves when using technology. Technology selfefficacy has an effect on technology-related behaviors such as the willingness to acquire technology skills, integrate technology, and hold positive attitudes towards technology (Sam, Othman,\&Nordin, 2005; Teo, 2009). Conversely, a high level of technology anxiety is negatively related to acquiring technology skills or resistance to the use of technology (Sam, Othman,\&Nordin, 2005; Simsek, 2011; Shu, Tu, \& Wang, 2011).This study investigated the role that self-efficacy played in shaping instructors' attitudes toward technology through measuring its impact on perceived usefulness and perceived ease of use.

\subsection{The conceptual research framework}

Figure 2 below is the conceptual research framework used for the study that incorporates the elements of the TAM and additional constructs.

Self-efficacy is expected to influence the Perceived Ease of Use and Perceived Usefulness of the technology, which in turn is expected to influence the instructor's attitudes toward technology. A positive attitude should subsequently lead to the integration of technology by the instructors in their teaching.

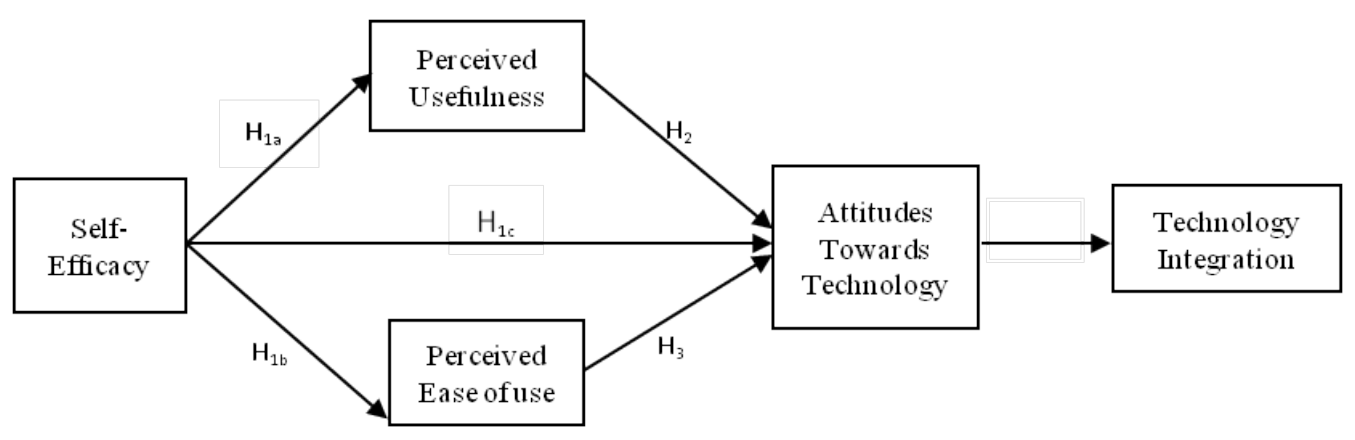

Figure 2. The conceptual research framework. 


\subsection{Research Hypotheses Statements}

The following hypotheses statements were set for the study:

- $\mathrm{H}_{1 \mathrm{a}}$ : Self-efficacy will have significant influence on perceived usefulness.

- $\mathrm{H}_{1 \mathrm{~b}}$ : Self-efficacy will have significant influence on perceived ease of use.

- $\mathrm{H}_{1 \mathrm{c}}$ : Self-efficacy will have significant influence on attitudes.

- $\mathrm{H}_{2}$ : Perceived usefulness will have significant effect on attitudes.

- $\mathrm{H}_{3}$ : Perceived ease of use will have significant influence on attitudes.

\section{Methodology}

\subsection{Sampling}

The sample population was drawn from UB instructors belonging to various departments. Simple random sampling was used to select the participants such that each member of the population had an equal opportunity to become part of the sample. The participants were drawn at random from all faculties at UB, namely, Faculty of Business (FoB), Faculty of Education (FoE), Faculty of Engineering and Technology (FET), Faculty of Health Sciences, Faculty of Social Sciences (FSS), Faculty of Science (FoS), and the School of Medicine. However, the numbers from each faculty varied depending upon the willingness of participants to take part in the study. The sample size was calculated using an online sample calculator from http:// www.macorr.com/sample-size-calculator.htm. The calculator required the (a) total number of instructors at UB (which is 850),(b) the confidence level, which was estimated to $90 \%$, and (c) confidence interval, set at $10 \%$ for its calculation of an appropriate sample size. The calculation gave a sample size of 63 .

\subsection{Data Collection Instrument}

This research study used a questionnaire to collect data. A survey questionnaire was used to collect data from the sample population. Reliability was established by using a pilot test, and collecting data from 20 subjects not included in the sample for validity purposes. The purpose of the pilot test was to check whether there were items that too difficult, confusing, or weak, and those items that did not correlate well with the total scale score (Slavin, 2007).

\subsection{Measurement of Constructs}

\subsubsection{Measurement of Attitudes toward Technology (ATT)}

ATT is a two-dimensional construct which included items that assessed Perceived Usefulness (PU) of technology and Perceived Ease of Use (PEU) of technology. The 'Perceived Usefulness' sub-scale measured whether the instructor found technology to be generally helpful, interesting, and enhancing their instructional activities. On the other hand, 'Perceived Ease of Use' subscale measured the perceived comfort level or difficulty of using technology and gave an indication on the level of confidence in handling and using the technology. A Technology Attitude Scale (TAS) was used to assess this construct. The scale had 8 survey items (see Appendix A). Each item was measured on a five-point Likert scale of strongly disagree (1), disagree (2), neither (3), agree (4), and strongly agree (5).

\subsubsection{Measurement of Technology Self-} efficacy (TSE) 
A TSE Scale was used to determine instructors' self-efficacy in using technology. The scale had nine survey items (see Appendix B). Literature shows similar studies have been conducted before (Teo\&Koh, 2010; Wang, Ertmer\& Newby, 2004), and therefore, instead of re-inventing the wheel the researchers used existing instruments to suit the UB situation with some adaptations. Each item was measured on a five-point Likert scale of Not Confident At All (1), Not Confident (2), Neutral (3), Confident (4), and Very Confident (5).

\subsubsection{Measurement of Technology Integration (TI)}

The study used a Technology Integration Scale (TIS) to assess the use of technology resources by instructors. The scale had nine survey items (see Appendix 3). Each item was measured on five-point Likert scale of strongly Never (1), Rarely (2), Sometimes (3), Often (4), and Very Often (5).

From these measurements the following null hypotheses were tested:

- $\mathrm{H}_{01 \mathrm{a}}$ : Self-efficacy will have no significant influence on perceived usefulness.

- $\mathrm{H}_{01 \mathrm{~b}}$ : Self-efficacy will have no significant influence on perceived ease of use.

- $\mathrm{H}_{01 \mathrm{c}}$ : Self-efficacy will have no significant influence on attitudes.

- $\mathrm{H}_{02}$ : Perceived usefulness will have no significant effect on attitudes.

- $\mathrm{H}_{03}$ : Perceived ease of use will have nosignificant influence on attitudes.

\subsection{Data analysis procedures}

After the data was collected, the data was entered to an Excel spreadsheet and organized before being imported to the Statistical Package for Research Software Program (SPSS). The analysis of data involved determining descriptive statistics, frequencies, correlation of variables, and conducting independent t-tests. The spread of the variables was calculated using the range and the standard deviation. From the standard deviation a standard error of the mean was calculated. Descriptive statistics can only show patterns or summarize data sets through the analysis of numeric data. Thus, inferential statistics was used to deduce from the sample data what the population might have thought and to make judgments of the probability that an observed difference between groups was a dependable one or one that might have happened by chance in the study (Trochim, 2006).

\section{Results}

\subsection{Descriptive statistics}

The findings of this study indicated that the technology integrationlevel among participants was about $70 \%$ with majority of participants indicating that they often used various technological resources in the delivery of their courses.Attitudes toward technology were regarded as the lecturers' general perceptions toward the use of technology in learning. This was a two-dimensional construct that measured items that assessed Perceived Usefulness of technology and Perceived Ease of Use of technology. The results indicated that about $75 \%$ of the participants found technology to be useful in their teaching, whereas, $48 \%$ indicated they found technology easy to use.Self-efficacy of participants in using technology was measured to be $90 \%$, with participants indicating high confidence level in using various technology resources in their teaching. 
Table 1. Biographical information of the participants

\begin{tabular}{lcc}
\hline Strata & Frequency & Percentage \\
\hline Male & 27 & 50 \\
Female & 27 & 50 \\
Trained in technology & 25 & 47.2 \\
Not trained in technology & 28 & 52.8 \\
\hline Age groups & 34 & 63 \\
\hline Young instructors $(\leq 50$ years $)$ & 20 & 37 \\
\hline Older instructors $(\geq 50$ years $)$ & & \\
\hline
\end{tabular}

\subsection{Results of the hypotheses testing}

\subsection{1. $H_{01 a}$ : Self-efficacy will have no significant influence on perceived usefulness.}

Bivariate correlations were run to relate self-efficacy (Dependent Variable) to Perceived Usefulness (Independent Variable). The results showed no statistically significant relationship between Self-efficacy $(\mathrm{M}=27.50$, $\mathrm{SD}=15.73)$ and Perceived Usefulness $(\mathrm{M}=$ $27.50, \mathrm{SD}=15.73)$, and the p-value was .23 ( $\square 0.05$ ).The null hypothesis was retained, and can be concluded that the relationship between the two variables were likely due to chance.

\subsection{2. $H_{01 b}$ : Self-efficacy will have no significant influence on perceived ease of use}

A bivariate correlation was run to relate Self-efficacy (DV) to Perceived Ease of Use (IV). The results indicated no statistically significant relationship between Self-efficacy $(\mathrm{M}=27.50, \mathrm{SD}=15.73)$ and Perceived Ease of Use $(\mathrm{M}=27.50, \mathrm{SD}=15.73)$, and the p-value was $.31(\square 0.05)$. The hypothesis was retained, and can be concluded that the relationship between the two variables was due to chance.

\subsection{3. $H_{01 c}$ : Self-efficacy will have no significant influence on attitudes}

A bivariate correlation was run to relate Attitude Towards Technology (DV) to Self-efficacy (IV). The results indicated a statistically significant relationship between Attitude Towards Technology $(\mathrm{M}=27.50, \mathrm{SD}$ $=15.73)$ and Self efficacy ICT skills $(\mathrm{M}=$ $27.50, \mathrm{SD}=15.73$ ), and a $\mathrm{p}$-value was found to be less than .05.The hypothesis was retained, and can be concluded that the relationship between the two variables was due to chance.

\subsection{4. $\mathrm{H}_{02}$ : Perceived usefulness will have no significant effect on attitudes}

The results indicated a statistically significant relationship between Attitude Towards Technology $(\mathrm{M}=27.50, \mathrm{SD}=15.73)$ and Perceived Usefulness $(\mathrm{M}=27.50, \mathrm{SD}=$ 15.73), and a p-value was found to be less than 
.05.The null hypothesis was rejected, and can be concluded that the relationship between the two variables was due to manipulation of the independent variable. The results suggested that Perceived Usefulness had a positive effect on attitudes.

\subsection{5. $\mathrm{H}_{03}$ : Perceived ease of use will have nosignificant influence on attitudes}

A bivariate correlation was run to relate Attitude Towards Technology (DV) to Perceived Ease of Use (IV). The results indicated a statistically significant relationship between Attitude Towards Technology (M $=27.50, \mathrm{SD}=15.73)$ and Perceived Ease of Use $(\mathrm{M}=27.50, \mathrm{SD}=15.73)$, and a $\mathrm{p}$-value was found to be less than .05.The hypothesis was rejected, and can be concluded that the relationship between the two variables was due to manipulation of the independent variable. The results suggested that Perceived Ease of Use had positive effect on attitudes.

\subsection{Discussion}

This study sought to determine factors that influence instructors' attitudes toward the integration of technology through the guidance of Technology Acceptance Model. According to this model and other previous studies, attitudes play a significant role in the adoption of technology in learning (Abukhzam\& Lee, 2010; Kim, Chun,\& Song, 2009). This study investigated factors that influenced this attitude as an effort to assist in cultivating positive attitudes among instructors that can promote technology integration in teaching and learning.

According to the TAM, attitudes towards technology are influenced by perceived usefulness and perceived ease of use. The results of this study confirmed this proposition as it showed that both perceived usefulness and perceived ease of use had positive significant influences on attitudes. Because these two variables have had such a significant impact on attitudes, it was very important to investigate the factors themselves to determine how they could be positively influenced with the ultimate goal of promoting technology integration. In this study, selfefficacy was brought in as an external variable that hypothesized to have had a significant influence on people's perception on the usefulness of technology and on its perceived ease of use. However, the results of this study indicated that self-efficacy had no influence on perceived usefulness and perceived ease, and also directly on the attitudes themselves.

The lack of influence of self-efficacy on perceived ease of use as shown in this study is intriguing because logically one can assume that if a person believes in his/her capability to perform an activity, then that should improve the person's perception toward its ease of use as shown by similar empirical studies (Lee \&Medlinger, 2011; Uwaifo, 2010). The fact that participants in this study reported high self-efficacy levels, which in turn did not impact their perception on the ease of use of technologies, indicated the complexities of human behavior towards accepting new phenomenon.

Self-efficacy is based on how people judge their abilities and according to Bandura (1994), this judgment is influenced by four main factors. These include mastery of experiences, social modeling, social persuasion, and psychological responses. The four factors impact self-efficacy in different ways depending on the nature of the task at hand. In a situation such as this present study, social modeling and social persuasion play a significant role in influencing people's selfefficacy. This study reports that considerable efforts have been made to train instructors to use technology and persuade them in different ways to use technology in their teaching, most 
notably through presentations made by other users who have had positive experiences with the use of technology. Therefore, people could eventually believe that they are now capable of carrying out the said activity, whereas in reality, they find it difficult. This shows taking consideration of the context in which self-efficacy is being reported and noting the possible factors that may play a significant role in influencing people's judgment of their capabilities are important.

In a similar manner, this study showed that self-efficacy did not influence perceived usefulness, which meant just because the participants believed that they had confidence in using technology, this did not necessarily mean that they found technology useful. A possible explanation to this lack of relationship between self-efficacy and perceived usefulness may be through Bandura's social modeling concept that posits people's ideas of usefulness can be influenced by observing how useful something is to other people, which eventually make them believe it is useful to them too. However, whether they actually find technology useful to their practices is what matters because that translates into positive attitudes. This lack of influence by self-efficacy on perceived usefulness goes some way in explaining why even after training and availing instructors the best of technologies they still do not use them; possibly because they may not have yet established this usefulness for their own benefit.This study also indicated that selfefficacy did not directly influence attitudes. Participants' self-belief in their capabilities to use technology did not impact their attitudes towards integration.

\subsection{Conclusion and recommendations}

The findings of this study clearly rules out self-efficacy as a determining factor in influencing people's attitudes toward technology. This is a departure from a majority of research findings that have often reported a significant influence of self-efficacy on perceived usefulness, perceived ease of use, and attitudes. These studies have subsequently recommended promotion of self-efficacy to positively influence people's attitudes toward new innovations. This study, on the other hand, questions self-efficacy as a credible departure point in predicting people's attitudes toward technology adoption. This paper argues to carefully analyze the context in which selfefficacy reports are made because self-reports may be more of what the participants believe is expected of them as opposed to what is real.

Established by this study and other literature, perceived usefulness and ease of use are important antecedents to positive attitudes. This study recommends further investigation into other factors that may positively influence these two variables beyond self-efficacy. These can include variables such as cultural background and teaching philosophy both of which can help explain why people behave the way they do. 


\section{References}

Abukhzam, M.,\& Lee, A. (2010).Workforce attitude on technology adoption and diffusion. The Build and Human Environment Review, 3, 60-71

Akbaba, S., \&Kurubacak, G. (1999).Teachers' attitudes towards technology.Computers in the Social Studies, 7(2), 833-836.

Anderson, S. E., Groulx, J. G., \&Maninger, R. M. (2011).Relationships among preservice teachers' technology-related abilities, beliefs, and intentions to use technology in their future classrooms...Journal of Educational Computing Research, 45(3), 321-338.

Ajzen, I. (1988). Attitudes, personality, and behavior. Chicago, IL: Dorsey Press.

Bandura, A., \&Schunk, D. H. (1981). Cultivating competence, self-efficacy, and intrinsic interest through proximal selfmotivation..Journal of Personality and Social Psychology, 41(3), 586-598.

Bandura, A. (1994). Self-efficacy.In V. S. Ramachaudran (Ed.), Encyclopedia of human behavior(pp. 71-81). New York, NY: Academic Press.

Bandura, A. (1986). Social foundations of thought and action: A social cognitive theory. Englewood Cliffs, NJ: PrenticeHall.

Bates, R., \&Khasawneh, S. (2007). Selfefficacy and college students' perceptions and use of online learning systems. Computers in Human Behavior, 23, 175 191.

Buarki, H., Hepworth, M., \& Murray, I. (2011). LIS students' ICT skills in Kuwait: Perspectives of employers, teaching staff and students. US-China Education Review, 1, 89-97

Ertmer, P. A.,\&Ottenbreit-Leftwich, A. (2010). Teacher technology change: How knowledge, confidence, beliefs, and culture intersect. Journal of Research on Technology in Education,42(3), 255-284.

Garland, K. J.,\&Noyes, J. M. (2004).Computer experience: A poor predictor of computer attitudes. Computers in Human Behavior, 20, 823-840.

Hardin, S. L. B. (2006). How teacher attitudes and administrator behaviors affect levelsof technology integration in the classroom. Dissertation, retrieved August 27,2009 from Dissertations \& Theses. (AAT 3225220).

Harper, K. C., Chen, K., \& Yen, D. C. (2004). Distance learning, virtual classrooms, and teaching pedagogy in the Internet environment.Technology in Society,26, 585-598.

Hsia, J.,\& Tseng, A. (2008).An enhanced technology acceptance model for e-learning systems in high-tech companies in Taiwan: Analyzed by Structural Equation Modeling. In IEEE Xplore digital library,International Conference on Cyberworlds(pp.39-44). Hangzhou: China

Jaradat, M. R. M., \&Faqih, K. M. S. (2014) Investigating the moderating effects of gender and self-efficacy in the context of mobile payment adoption: A developing country perspective. International Journal of Business and Management, 9(11), 147169

Jong, D., \& Wang, T. (2009).Student Acceptance of Web-Based Learning System.In Proceedings of the 2009 InternationalSymposium on Web Information Systems and Applications (pp. 533-536). Nanchang: Academy Publisher.

Kim, Y.J., Chun, J.U., \& Song, J. (2009). Investigating the role of attitude in technology acceptance from an attitude strength perspective. International Journal of Management, 29(1), 67-77.

Kotrlik, J.W., \&Redmann, D.H. (2009). Technology adoption for use in instruction by secondary technology education 
teachers. Journal of Technology Education, 21(1), 44-59.

Lunceford, B. (2009).Reconsidering technology adoption and resistance: Observations of a semi-luddite. Hampton Press Inc. and MEA.EME. 29-48. Retrieved November 3, 2012, from http://www.academia.edu/510375/ Reconsidering_Technology_Adoption and_Resistance_Observations_of_a Semi-Luddite

Mafote, S., \&Oluka, S.(2012, May).A Tapestry of eLearning at the University of Botswana.Paper presented at the eLearning Africa8th International Conference on ICT for Development, Education and Training. Cotonou, Benin.

Masalela, R. K. (2009). Potential benefits and complexities of blended learning in higher education: The case of the University of Botswana. Turkish Online Journal of Distance Education, 10(2), 1302-6488.

Molelu, G.B., \&Thomas, P.Y. (2008). E-learning adoption at the University of Botswana. Paper presented at the Eduvate 2008 Conference "Education Innovation Quest: A Century in the Service of Knowledge." University of Pretoria, South Africa. Retrieved from UPSpace Institutional Repositorywebsite: http:// repository.up.ac.za/handle/2263/7497

Moser,F.Z. ( 2007). Faculty adoption of educational technology.EDUCAUSE Review Online. Retrieved November 3, 2012, fromhttp://www.educause.edu/ ero/article/faculty-adoption-educationaltechnology

Mutula, S. M. (2004). E-learning initiative at the University of Botswana: Challenges and opportunities.Campus-Wide Information Systems, 19(3), 99-109.

Oigara, J. N., \& Wallace, N. (2012).Modeling, training, and mentoring teacher candidates to use SMART board technology.Issues in Informing Science and Information
Technology, 9, 297-315.

Ormrod, J. E. (2006). Educational psychology: Developing learners (5th ed.). Upper Saddle River, N.J.: Pearson/Merrill Prentice Hall.

Oye, N.D., Salleh, M., \&Iahad, A.N. (2011). Challenges of E-learning in Nigerian University based on the experience of developed countries. International Journal of Managing Information Technology,3(2), 39-48.

Park, N., Lee, K. M., \& Cheong, P. H. (2007). University instructors' acceptance of electronic courseware:An application of the Technology Acceptance Model. Journal of Computer-Mediated Communication,13(1), 163-186. doi: 10.1111/j.1083-6101.2007.00391.x

Park, S. Y. (2009). An analysis of the technology acceptance model in understanding university students' behavioral Intention to use e-Learning. Educational Technology \& Society,12(3), 150-162.

Rakes, G.C., Fields, V.S., \& Cox, K.E. (2006). The influence of teachers'technology use on instructional practices. Journal of Research on Technology in Education, 3(4), 409-424.

Ramdass, D.H. (2011).Improving fifth grade students' mathematics self-efficacy calibration and performance through self-regulation training. New York: BiblioLabsII

Sam, H. K., Othman, A. E. A., \&Nordin, Z. S. (2005). Computer Self-Efficacy, Computer Anxiety, and Attitudes toward the Internet: A Study among undergraduates in Unimas. Educational Technology \& Society, 8(4), 205-219.

Seferoğlu, S. S. (2007). Pre-service teachers' perceptions of their computer self-efficacy. International Journal of the Computer, the Internet and Management, 15(SP3), 35.135.4. 
Simsek, A. (2011). The relationship between computer anxiety and computer selfefficacy.Contemporary Educational Technology, 2(3), 177-187

Shu, Q., Tu, Q., \& Wang, K. (2011).The impact of computer self-efficacy and technology Dependence on ComputerRelated Technostress: A social cognitive theory perspective. International Journal of Human- Computer Interaction, 27(10), 923-939

Staples, D.S., Hulland, J.S.,\& Higgins, C.A., (1999).A self-efficacy theory explanation for the management of remote workers in virtual organizations. Organization Science, 10(6), 758-776.

Straub, E. (2009). Understanding technology adoption: Theory and future directions for informal learning. Review of Educational Research,79(2), 625-649.

Sun, H., and Zhang, P. (2006). The role of moderating factors in user technology acceptance.International Journal of Human-Computer Studies,64(2), 53-78.

Tabata, L.N., \&Johnsrud, L.K. (2008). The impact of faculty attitudes towardtechnology, distance education, and innovation. Research in Higher Education,49, 625-646.

Tella, A., Ayeni, C. O., \&Omoba, R. O. (2007).Self-Efficacy and Use of Electronic Information as Predictors of Academic Performance.Electronic Journal of Academic and Special Librarianship, 8(2).Retrieved from http:// southernlibrarianship.icaap.org/content/ v08n02/tella_a01.html

Teo, T. (2009).Modelling technology acceptance in education: A study of preservice teachers.Computers \& Education, 52(2), 302-312.

Teo, T., Luan, W. S., \& Sing, C. C. (2008). A cross-cultural examination of the intention to use technology between Singaporean and Malaysian pre-service teachers: An application of the Technology Acceptance Model (TAM). Educational Technology \& Society, 11(4), 265-280.

Thurab-Nkhosi, D., Marilyn Lee, M., \&Gachago, D. (2005).Preparing Academic Staff for e-Learning at the University of Botswana.RetrievedJuly 28, 2011 from http://innovateonline.info/pdf/vol2 issue1/Preparing_Academic_Staff_ for_e-Learning_at_the_University_of Botswana.pdf

Trochim, W. M. K. (2006). Descriptive Statistics.Research Methods Knowledge Base. Retrieved April 25, 2012 from http://www.socialresearchmethods.net/kb/ statdesc.php

Turner, L. (2005). 20 Technology Skills Every Educator Should Have. Retrieved January 5, 2012, from http://thejournal.com/ articles/2005/06/01/20-technology-skillsevery-educator-should-have.aspx

Uwaifo, S. (2010).Computer self-efficacy as predictor of librarians' perceived ease of use of automated library systems in Nigerian university libraries. The Information Technologist, 6(2).Retrieved from http://www.ajol.info/index.php/ict/ article/view/52698

Van Braak J. (2001) Factors influencing the use of computer mediated communication by teachers in secondary schools. Computers \& Education, 36, 41-57.

Venkatesh, V., Morris, M. G., Davis, G. B., \& Davis, F. D. (2003). User acceptance of information technology: Toward a unified view. MIS Quarterly, 27(3), 425-478.

Vesisenaho, M., Valtonen, T., Kukkonen, J., Havu-Nuutinen, S., Hartikainen, A.,\&K€rkk€inen, S. (2010). Blended learning with everyday technologies to activate learners' collaborative learning. Science Education International, 21(4), 272-283.

Wang, L., Ertmer, P. A., \& Newby, T. J. (2004).Increasing Preservice Teachers' 
Self-Efficacy Beliefs for Technology Integration.Journal of Research on Technology in Education, 36(3), 231.

Weinberg, R. S., Gould, D., \& Jackson, A. (1979). Expectations and performance: An empirical test of Bandura's self-efficacy theory. Journal of Sport Psychology, 1(4), 320-331.

Wixom, B.H., \&Todd, P.A. (2005).

A theoretical integration of user satisfactionand technology acceptance. Information Systems Research, 16(1), 85102.

\section{Contact the Author}

Molefe Mookana Motshegwe

Doctor,eLearning Course Design

Team,University of Botswana

Centre for Academic Development

Private Bag UB710

Gaborone, Botswana

Email:motshegwem@mopipi.ub.bw

\section{Tshepo Batane}

University of Botswana

Email:batane@mopipi.ub.bw

\section{Appendix: Survey Questionnaire}

\section{Section 1: Attitudes towards Technology}

Indicate with an $\mathrm{X}$ your response to the statements made below

[Scale: 1 = Strongly Disagree; 2 = Disagree; 3 = Neither; 4 =Agree; $5=$ Strongly Agree $]$

\begin{tabular}{|l|l|l|l|l|l|l|}
\hline Statement & 1 & 2 & 3 & 4 & 5 & NA \\
\hline $\begin{array}{l}\text { Technology help me to do my work } \\
\text { better }\end{array}$ & & & & & & \\
\hline $\begin{array}{l}\text { Technology make it possible to work } \\
\text { more productively }\end{array}$ & & & & & & \\
\hline $\begin{array}{l}\text { Technology can allow me to do more } \\
\text { interesting and imaginative work }\end{array}$ & & & & & & \\
\hline $\begin{array}{l}\text { Technology can be used to do most } \\
\text { things that I cannot do myself }\end{array}$ & & & & & & \\
\hline $\begin{array}{l}\text { Technology c a n en an ce the } \\
\text { presentation of my work to a degree } \\
\text { which justifies the extra effort }\end{array}$ & & & & & & \\
\hline $\begin{array}{l}\text { My interaction with technology is clear } \\
\text { and understandable. }\end{array}$ & & & & & & \\
\hline $\begin{array}{l}\text { I find it easy to get technology to do } \\
\text { what I want it to do }\end{array}$ & & & & & & \\
\hline $\begin{array}{l}\text { I find technology (e.g., computers, } \\
\text { data projector, Learning Management } \\
\text { systems, etc.) easy to use }\end{array}$ & & & & & & \\
\hline
\end{tabular}




\section{Section 2: Technology Self-Efficacy}

Indicate with an $\mathrm{X}$ your response to the statements made below

[Scale: $1=$ Not Confident At All; $2=$ Not Confident; $3=$ Neutral; $4=$ Confident; $5=$ Very Confident]

\begin{tabular}{|c|c|c|c|c|c|}
\hline Basic Technology Skills & 1 & 2 & 3 & 4 & 5 \\
\hline How confident are you to ... & & & & & \\
\hline $\begin{array}{l}\text { use word processor to create, edit and format } \\
\text { documents for specific purposes. (e.g., Microsoft } \\
\text { Word) }\end{array}$ & & & & & \\
\hline $\begin{array}{l}\text { use presentation Software (e.g., Microsoft } \\
\text { PowerPoint) for classroom delivery }\end{array}$ & & & & & \\
\hline $\begin{array}{l}\text { use data projector with a PC or laptop to do } \\
\text { presentations }\end{array}$ & & & & & \\
\hline $\begin{array}{l}\text { use spreadsheet to record data, compute simple } \\
\text { calculations and represent data in the form of tables } \\
\text { and graphs (e.g., Microsoft Excel) }\end{array}$ & & & & & \\
\hline$\underline{\text { Social Media Skills }}$ & & & & & \\
\hline $\begin{array}{l}\text { use email (e.g., Hotmail, Outlook, Yahoo, Gmail, } \\
\text { etc.) for communication }\end{array}$ & & & & & \\
\hline $\begin{array}{l}\text { use social networks (e.g.,facebook, twitter, etc.) to } \\
\text { communicate or collaborate with my colleagues }\end{array}$ & & & & & \\
\hline$\underline{\text { Web-Based Skills }}$ & & & & & \\
\hline use Internet to search for information and resources & & & & & \\
\hline $\begin{array}{l}\text { copy a block of text from a web site and paste it to a } \\
\text { document in a word processor }\end{array}$ & & & & & \\
\hline $\begin{array}{l}\text { download an image from a web site and save it to } \\
\text { my desktop }\end{array}$ & & & & & \\
\hline
\end{tabular}




\section{Section 3: Technology Self-Efficacy}

Indicate with an $\mathrm{X}$ your response to the statements made below.

[Scale: 1 = Never; 2 = Rarely; $3=$ Sometimes; 4 = Often; $5=$ Very Often $]$

\begin{tabular}{|l|l|l|l|l|l|}
\hline & 1 & 2 & 3 & 4 & 5 \\
\hline I use ... & & & & & \\
\hline $\begin{array}{l}\text { technology in my course to enhance student } \\
\text { learning }\end{array}$ & & & & & \\
\hline $\begin{array}{l}\text { instructional technology in my course to improve } \\
\text { my teaching. }\end{array}$ & & & & & \\
\hline $\begin{array}{l}\text { Internet for ideas when developing course material } \\
\text { and work }\end{array}$ & & & & & \\
\hline $\begin{array}{l}\text { Learning Management System (i.e., Moodle, } \\
\text { Blackboard/ WebCT) }\end{array}$ & & & & & \\
\hline $\begin{array}{l}\text { email in Moodle/Blackboard to keep students up-to- } \\
\text { date on grades and student progress }\end{array}$ & & & & & \\
\hline $\begin{array}{l}\text { Excel spread sheet or Online grade book to analyse } \\
\text { students' work }\end{array}$ & & & & & \\
\hline $\begin{array}{l}\text { simulations and games (i.e., reproducing the } \\
\text { characteristics of a system or process) }\end{array}$ & & & & & \\
\hline $\begin{array}{l}\text { data projector in my lectures } \\
\text { or other Social networks (e.g., facebook, twitter) } \\
\text { so encourage communicate or collaborate with my } \\
\text { students }\end{array}$ & & & & & \\
\hline
\end{tabular}

